J Arid Land (2013) 5(4): 439-451

doi: $10.1007 / \mathrm{s} 40333-013-0175-\mathrm{x}$

jal.xjegi.com; www.springer.com/40333

\title{
Phytogeography of the northeastern coast of the Caspian Sea: native flora and recent colonizations
}

\author{
Liliya A DIMEYEVA* \\ Institute of Botany and Phytointroduction, Almaty 050040, Kazakhstan
}

\begin{abstract}
The northeastern coast of the Caspian Sea is one of the youngest territories for plant colonization in Kazakhstan, and the flora of the most recent portion of this coastal area, the New Caspian marine plain, was chosen to study phytogeographical characteristics of plant species, especially as related to alien origin and invasive potential. Because of the recent formation of this flora, I expected that a large proportion of the species may be alien and invasive. After compiling a comprehensive species list from previous research, I identified the taxonomic, life form, ecological, and geographical structures of the flora. The area belongs to the northern type of deserts with continental climate and low annual precipitation. Taxonomic and life form structures show that the flora is specific to Central Asian deserts. Ecological structure demonstrates a high percentage of halophytes, which resulted from their adaptation to soil salinity and shallow ground waters that occur throughout the study area. Geoelements of the flora indicate allochtonous properties of the flora (i.e. species derived from areas outside the study area) with a low proportion of native (Caspian) plants. Alien species are estimated to comprise $12 \%-19 \%$ of the flora. Although some species have invasive features, severe arid environmental conditions and high salinity of soils and ground waters decrease invasive capacity of exotic plants. However, a threat of expansion of potentially invasive plants exists in the New Caspian marine plain due to the fast growth of anthropogenic habitats associated with recent oil developments.
\end{abstract}

Keywords: alien; invasive plants; geographical distribution; the Caspian Sea coast

Citation: Liliya A DIMEYEVA. 2013. Phytogeography of the northeastern coast of the Caspian Sea: native flora and recent colonizations. Journal of Arid Land, 5(4): 439-451. doi: 10.1007/s40333-013-0175-x

The northeastern coast of the Caspian Sea is a low-lying, arid plain within Kazakhstan that also includes large areas of marshlands in its eastern sector. This coastal area is part of the Caspian depression that today can reach as low as $-27 \mathrm{~m}$ below the Baltic Sea level (bsl), which is commonly used as a reference point for sea level in the Caspian Sea basin. This coastal area has experienced oscillations in the level of the Caspian Sea due to interrelationship among sea level, climate, and runoff from rivers in its catchment basin, which all varied during the alternations between glacial and interglacial periods. The total change in sea level was more than $100 \mathrm{~m}$ during the Late Pleistocene and approximately $20 \mathrm{~m}$ during the Holocene. Transgressions were highest during the first (i.e. cooling) half of glacial epochs when evaporation from the surface of the basin significantly decreased, leading to increased lake level (Svitoch, 1991; Lavrushin, 2001; Kislov et al., 2012). Sea level for high (transgressive) stages is reliably established from ancient shorelines (Kislov et al., 2012). The early Khvalynian stage is ranked as the highest transgression (rise of sea level to $+50 \mathrm{~m}$ above bsl). The late Khvalynian stage has shoreline at $0 \mathrm{~m}$.

The modern history of the Caspian Sea region is called the New Caspian stage and began at the start of

"Corresponding author: Liliya A DIMEYEVA (E-mail: 1.dimeyeva@mail.ru) Received 2012-11-27; revised 2013-03-04; accepted 2013-05-02

(C) Xinjiang Institute of Ecology and Geography, Chinese Academy of Sciences, Science Press and Springer-Verlag Berlin Heidelberg 2013 
the Holocene (10,000 B.P.). The youngest portion of the marine plain in the New Caspian stage is called the New Caspian plain between $-22 \mathrm{~m}$ and the present coast line of the Caspian Sea (Akiyanova et al., 2006). Within the New Caspian plain, two marine terraces are identified. The first marine terrace (late New Caspian plain) is found at elevations from $-27 \mathrm{~m}$ to $-25.5 \mathrm{~m}$. The second one (early New Caspian plain) is found at elevations from $-25.5 \mathrm{~m}$ to $-22 \mathrm{~m}$. These two terraces were formed during different periods. The early New Caspian plain became land surface in the $17^{\text {th }}$ century. The formation of the late New Caspian plain started after sea regression at the turn of the $18^{\text {th }}-19^{\text {th }}$ centuries. The last short-term sea-level cycle started with a sea-level fall by $3 \mathrm{~m}$ from 1929 to 1977, which then was followed by a $3 \mathrm{~m}$ rise from 1977 to 1995 that flooded an area of $93 \times 10^{3} \mathrm{hm}^{2}$ (Diarov et al., 2003). Since that time, smaller oscillations have taken place (Aladin and Plotnikov, 2000). By 2000, the level of Caspian Sea had stabilized at $-27 \mathrm{~m}(2 \mathrm{~m}$ above the 1977 level).

Formation of flora and vegetation communities in the coastal area has been greatly impacted from the Caspian Sea transgressive and regressive stages that occurred during its history. The age of the New Caspian plain, i.e. the youngest territory in this region, varies from 80 to 400 years. Because of this recent age, vegetation associations in the marine plain are still at various stages of successional development (Dimeyeva, 2011). Thus, the New Caspian plain area is of great interest to better understand processes of colonization and establishment of plant species/communities.

The Caspian depression is situated in Russia and Kazakhstan and occupies $2 \times 10^{5} \mathrm{~km}^{2}$. The territory stretches for $550 \mathrm{~km}$ from North to South and $770 \mathrm{~km}$ from West to East. Our study focused on the northeastern coast of the Caspian Sea in Kazakhstan. The flora in different parts of the Caspian depression has been studied by many authors (Levina, 1964; Dzharmagambetov, 1987; Lazareva, 2003; Laktionov, 2010, etc.). Lazareva (2003) investigated the Kalmykian coast (Northwestern Caspian coast; Russia) of the Caspian Sea. She found 276 species of vascular plants within the New Caspian marine plain and conducted taxonomic, ecological, and life form analyses. My colleague and I (Dimeyeva and Pankratova, 2011) studied the flora for the Kazakhstan part of the Caspian shore. However, no study has examined the geographical distribution of alien and invasive plants among the species in this region. The study of the flora in a historically young coastal area gives important information about migration patterns that allow us to predict future invasions. Furthermore, the northeastern coast of the Caspian Sea is rich in oil and gas resources. At present time, 43 oil and gas fields are being developed, including the unique Tengiz oil field (Diarov et al., 2003). This development of the oil industry and its related infrastructure has likely accelerated the arrival and dispersal of alien species, many of which can invade pristine natural habitats.

\section{Materials and methods}

\subsection{Study area}

The study area encompasses territory from the New Caspian marine plain, as defined by the current sea level, to the ecotone with the Khvalynian plain $(-27 \mathrm{~m}$ to $-20 \mathrm{~m}$ above bsl) within the Caspian depression (Fig. 1). The area has an average precipitation of 150-200 $\mathrm{mm}$ or less per year. Annual average air temperature is $7.6^{\circ} \mathrm{C}-8.7^{\circ} \mathrm{C}$. Wide development of dam sites is typical of the coastal area. These dams were built to protect oil fields from flooding caused by strong wind. Wind-induced surges of 0.8 to $3.0 \mathrm{~m}$ high occur in the northeastern Caspian, and surges may penetrate 20-30 $\mathrm{km}$ inland and remain in shore depressions for 15-20 days (Caspian Sea, 2006). The most significant surges take place in the shallow waters of the eastern coast near the mouth of the Emba River. Most frequent surges occur in summer (June-July) and in autumn (October-November) and are associated with the passage of high-season seafarers-the continuous and strong winds of run-up direction. Salinity of the sea water in the Ural River mouth, one of the lowest locations in the region, is $1 \%{ }_{0}-2 \%$; in the shallow northeastern part of the sea, salinity varies from $5 \%$ to $8 \%$. Soils of the territory are characterized by low content of humus, significant presence of carbonates, and wide 


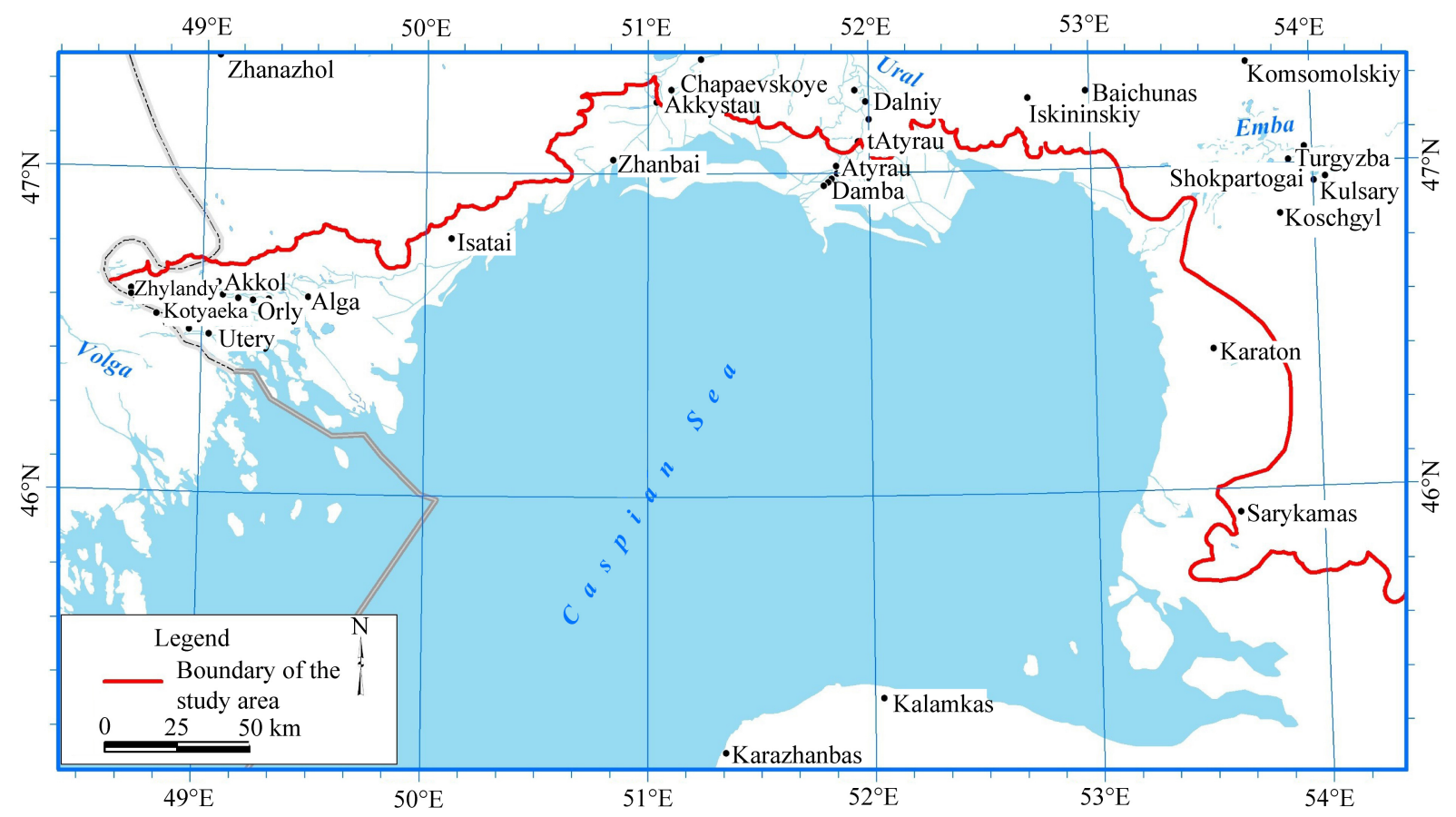

Fig. 1 Location of the study area

distribution of solonetz and solonchak soils. Zonal type of soils is brown desert. Ground waters are heavily mineralized and lay at a depth of no more than $4.5 \mathrm{~m}$ (Faizov, 1970).

Vegetation cover of the New Caspian marine plain is represented by different plant associations, and species composition and distribution in turn depends on how long the land surface has been exposed, soil conditions, and successional stage of the vegetation association. Three types of primary successions have been recognized in the New Caspian marine plain: psammosere, halosere, and meadow sere (Dimeyeva, 2011). They differ by ecological conditions, temporal dynamics, developmental stages, and dominants in plant communities. Psammosere is typical for the northern Caspian coast near the southern fringe of the Volga-Ural sands. Halosere is most prevalent from the Ural River delta and east along the northeastern shoreline in sediments of heavy texture and high salinity. Meadow sere characterizes vegetation of modern and ancient deltas of the Ural and Emba Rivers. At initial stages, halophytes (Suaeda acuminata, S. prostrata, S. salsa, Salicornia europaea) colonize the marshland. In the active tidal belt, communities of dwarf sub-shrub (Halocnemum strobilaceum) and halophytic grasses
(Puccinellia distans, P. dolocholepis, Aeluropus littoralis) are widely distributed. Outside the zone of tidal influence appear ephemerals (Eremopyrum triticeum, E. orientale, Lepidium perfoliatum, Senecio noeanus), desert moss (Tortula desertorum), and shrubs (Nitraria schoberi, Tamarix laxa). Late seral and climax plant communities are rare and mostly occur near the limits of the Khvalynian marine plain. The final stages of primary succession include communities of: Artemisia arenaria and Artemisia lerchiana for psammosere; Anabasis salsa and Artemisia terrae-albae for halosere; and Anabasis salsa and Artemisia pauciflora for meadow sere.

\subsection{Methods}

Botanical specimens were collected during studies on flora and vegetation in 1998-2012 for scientific projects in the coastal area related to the creation of nature preserves and related to environmental impact assessments for the Tengiz, Novobogatinskoe, Kosshagyl, Aiyrshagyl, Munaily, Karabatan, oil fields (19982008). These projects studied both natural and anthropogenic disturbed habitats to understand human impact on biodiversity. I also used lists of species that were collected along the Kazakhstani part of the Cas- 
pian Pipeline Consortium, which were kindly provided by my colleagues Drs. Sultanova and Stogova, as well as lists of species from the literature (Globally important, 2007).

Collection of herbarium specimens was conducted simultaneously with the study of vegetation cover in all habitats. A Vegetation Description Form (VDF) was used to record vegetative and environmental characteristics in $10 \mathrm{~m} \times 10 \mathrm{~m}$ sample plots. The form included: GPS coordinates, elevation, topography, soil type, percent cover, species list, etc. I used these VDFs to identify plots located within the New Caspian marine plain based on elevation between -27 and $-22(-20)$ $\mathrm{m}$ bsl, landscape features, soils and vegetation. Identification of plants was conducted using the 9-volume "Flora of Kazakhstan" (1956-1966) and taxonomic revision of species names developed by Cherepanov (1995).

Because there is no database of alien and invasive plants in Kazakhstan, I used the databases of alien (AliS, 2005) and invasive ("Black Book") (Vinogradova et al., 2009) plants of Eastern Europe (Middle Russia) and DAISIE (Delivering Alien Invasive Species Inventories for Europe, 2008) to identify these types of species.

\section{Results and discussion}

\subsection{Overall composition of the Flora}

Flora of the Caspian Sea shore within New Caspian marine plain consists of 343 species belonging to 43 families and 164 genera (Table 1). Species from Chenopodiaceae, Asteraceae, Poaceae, Brassicaceae and Polygonaceae families prevail. The most important genera are Artemisia (11 spp.), Atriplex (11 spp.), Salsola (10 spp.), Suaeda (9 spp.), Astragalus (6 spp.), Petrosimonia (7 spp.), Allium (6 spp.), Lepidium (5 spp.), Chenopodium (5 spp.), Climacoptera (5 spp.), Leymus (5 spp.), and Limonium (5 spp.).

\subsection{Overall life form spectrum}

I used the Raunkiaer (1910) system to identify plant life forms, in which subdivisions are based on placement of the plant's growth-point (bud) during seasons with adverse conditions (cold, dry seasons). Life forms within the New Caspian plain are represented by the
Table 1 The dominant plant families of the flora

\begin{tabular}{lccc}
\hline Plant family & $\begin{array}{c}\text { Number of } \\
\text { genera }\end{array}$ & $\begin{array}{c}\text { Number of } \\
\text { species }\end{array}$ & $\begin{array}{c}\text { Percentage of } \\
\text { species }\end{array}$ \\
\hline Chenopodiaceae & 27 & 85 & 24.8 \\
Asteraceae & 26 & 48 & 14.0 \\
Poaceae & 21 & 35 & 10.2 \\
Brassicaceae & 17 & 26 & 7.6 \\
Polygonaceae & 5 & 21 & 6.1 \\
Fabaceae & 10 & 20 & 5.8 \\
Boraginaceae & 8 & 17 & 5.0 \\
Cyperaceae & 4 & 9 & 2.6 \\
Caryophyllaceae & 3 & 6 & 1.8 \\
Alliaceae & 1 & 6 & 1.8 \\
Additional families & 43 & 71 & 20.7 \\
Total & 164 & 343 & 100 \\
\hline
\end{tabular}

following subdivisions: therophytes (41\%), hemicryptophytes $(35 \%)$, chamaephytes $(10 \%)$, phanerophytes $(6 \%)$, geophytes $(6 \%)$, and hydrophytes $(2 \%)$. The most numerous group is therophytes, which are annual plants that survive unfavorable seasons in the form of seeds and complete their life-cycle during favorable seasons. They are mainly represented by ephemerals (Alyssum turkestanicum, Meniocus linifolius, Strigosella circinata, S. grandiflora, Arnebia decumbens, Asperugo procumbens, etc.). Annual species from the Chenopodiaceae family (Salicornia europaea, Suaeda acuminata, Suaeda prostrata, Climacoptera crassa, Petrosimonia triandra, etc.) often play a dominant role in plant communities, especially as pioneers in the first stages of primary successions (Dimeyeva, 2011). Hemicryptophytes are perennial herbs with buds at or near the soil surface. Some of them can dominate in plant communities (Agropyron fragile, Leymus ramosus, Phragmites australis, Stipagrostis pennata, Aeluropus littoralis, Alhagi pseudalhagi, Limonium caspium, Karelinia caspia, etc.). Chamaephytes have buds on persistent shoots near the ground and include woody plants with perennating buds borne close to the ground but no more than $25 \mathrm{~cm}$ above the soil surface. Chamaephytes are the most typical life form for deserts of Central Asia and include suffrutescent dwarf subshrubs and subshrubs whose shoots senesce annually to basal buds. The main chamaephyte dominants in the New Caspian marine plain are dwarf subshrubs of the 
genera Artemisia and Kalidium along with Suaeda physophora, Kochia prostrata, and Nanophytum erinaceum. The most widespread is Halocnemum strobilaceum-a typical species in saline habitats with shallow ground water. Phanerophytes are shrubs with buds more than $25 \mathrm{~cm}$ above soil surface and on the New Caspian plain include species of genera Calligonum and Tamarix along with Salsola arbuscula, Astragalus ammodendron, Halimodendron halodendron, Nitraria schoberi, etc. Geophytes have their perennating structures within the ground and are further subdivided into rhizome, stem-tuber, root-tuber, bulb, and root geophytes. Geophytes are represented on the New Caspian plain by ephemeral species: geophytes with bulbs (Tulipa schrenkii, Allium caspium, Gagea reticulata, etc.); geophytes with rhizomes/roots or tubers (Rheum tataricum, Megacarpaea megalocarpa, Ferula caspica, etc.) and parasitic geophytes (Felipanche kelleri, and $F$. uralensis). Hydrophytes are similar to geophytes except that the perennating organs are submerged under water. This group is the smallest in number on the New Caspian plain (6 species) and includes Typha latifolia, Scirpus lacustris, and Scirpus tabernaemontani, etc.

\subsection{Overall ecological structure}

The primary ecological groups of species have been identified based on water requirements. Plant species are grouped into xerophytes, mesoxerophytes, mesophytes, xeromesophytes, hydrophytes, hygrophytes, and mesohygrophytes (Table 2). Xeromesophytes, mesophytes and mesoxerophytes prevail. Xeromesophytes mostly consist of ephemeral plants (Hyalea pulchella, Koelpinia linearis, Eremurus inderensis, Megacarpaea megalocarpa, Gagea reticulata, etc.) that are very common in Central Asian deserts. The flora of the New Caspian plain also includes a high percentage of halophytes (113 species, 33\%) that are adapted to the soil of high salt concentration. Abundance of halophytes is related to high salinity of soil and shallow ground water and reflects the short history of vegetation formation after the last regression of the sea.

\subsection{Overall geographic structure}

Analysis of the geographic affinities for species is
Table 2 Ecological structure of the flora

\begin{tabular}{|c|c|c|}
\hline Type & Number of species & Percentage $(\%)$ \\
\hline Xerophytes & 44 & 12.8 \\
\hline Halo-xerophytes & 16 & 4.7 \\
\hline Psammo-xerophytes & 4 & 1.2 \\
\hline Mesoxerophytes & 68 & 19.8 \\
\hline Halo-mesoxerophytes & 34 & 9.9 \\
\hline Psammo-mesoxerophytes & 19 & 5.5 \\
\hline Mesophytes & 70 & 20.4 \\
\hline Halo-mesophytes & 19 & 5.5 \\
\hline Psammo-mesophytes & 2 & 0.6 \\
\hline Hygro-mesophytes & 7 & 2.0 \\
\hline Xeromesophytes & 148 & 43.2 \\
\hline Halo-xeromesophytes & 42 & 12.3 \\
\hline Psammo-xeromesophytes & 8 & 2.3 \\
\hline Hydrophytes & 6 & 1.8 \\
\hline Hygrophytes and mesohygrophytes & 5 & 1.5 \\
\hline Halo-hygrophytes & 2 & 0.6 \\
\hline Parasites & 2 & 0.6 \\
\hline
\end{tabular}

derived from botanical and geographical regionalization of the Ancient Mediterranean subdominion (Lavrenko, 1962), the Eurasian steppe region (Lavrenko, 1970), the desert region of Kazakhstan and Middle Asia (Rachkovskaya et al., 2003), and the Map of Botanical-geographic Regionalization for National Atlas of Kazakhstan (2010). Botanical-geographic regionalization objectively divides an existing region on the basis of similarity and differences of vegetation cover and then unifies the subdivisions into a hierarchical system. The country of Kazakhstan is located in two botanical-geographic regions: Eurasian steppe and Sahara-Gobi desert. The steppe portions of Kazakhstan are associated with the Black Sea-Kazakhstan subregion of the Eurasian steppe region. It has three provinces: West-Siberian forest-steppe (I) and TransVolga-Kazakhstan steppe (II) in plains, and South Altai (III) in the mountains. Desert portions are associated with the Iran-Turan subregion (IV-VIII) of the Sahara-Gobi desert region. North Nuran (IV), South Turan (VI), and Junggar (V) are provinces in plains; Junggar-North Tian Shan (VII) and Mountain Middle Asian (VIII) are mountain provinces. Plain provinces are divided into subprovinces based on distinctive zones. These zones are structured because of distinc- 
tive sets of edaphic variants of plant communities, groups of specific plant associations (seldom formations) that may include endemic species, and geoelements and dominants of plant communities (Rachkovskaya et al., 2003). The study area belongs to the Sahara-Gobi desert region, Iran-Turan subregion, North Turan province, and Caspian (IVa, to the west of the Ural River) and West-North-Turan (IVb, to the east of the Ural River) subprovinces.

Fifteen types of geoelements occur in the northeastern coast of the Caspian Sea (Fig. 2). The majority of species (38\%) have Mediterranean and Eastern Mediterranean affinities, which are associated with the eastern part of the Ancient Mediterranean territory. Typical desert species of Irano-Turanian, Turanian, Northern Turanian, and Junggar areas comprise $18 \%$ of the flora. Autochthonic Caspian and Aralo-Caspian species (i.e. species evolved locally) represent only a small part of the flora (nine species, 2.6\%) and include Corispermum aralo-caspicum, Suaeda salsa, S. crassifolia, Asparagus inderiensis, Astragalus amarus, Artemisia santonica, Centaurea arenaria, Astragalus karakugensis, and Melilotus polonicus. Endemics of Kazakhstan (1.5\%) consist of Kalidium schrenkianum, Petrosimonia hirsutissima, Atriplex pungens, Gypsophila krascheninnikovii, and Tragopogon dubjanskyi. Pontic-northern Turanian (-Turanian, -Irano-Turanian), Northern Turanian-western Siberian and Trans-VolgaKazakhstan steppe species are found from the Black Sea to western Siberia with radiations into desert areas.

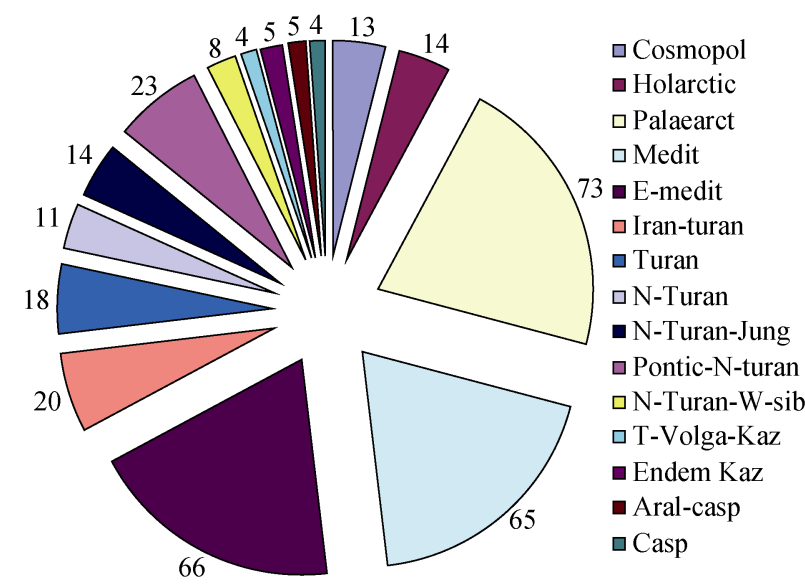

Fig. 2 Geographic structure of the flora; the plant species numbers of every geographic structure are presented.
Black Sea (Pontic)-Kazakhstan steppe subregion species (Lavrenko, 1970) comprise 10\% of the flora. Among them there are species of Stipa and Limonium genera (Stipa sareptana, S. richteriana, S. capillata, Limonium sareptanum, L. bungei, and L. caspium) as well as Puccinellia dolicholepis, Atraphaxis decipiens, Tulipa schrenkii, etc. Species of wide geographical distribution (Cosmopolitan, Holarctic, Palaearctic) comprise $29 \%$ of the flora.

\subsection{Potential alien and invasive plants}

I used three sources of information to compile a preliminary list of potential alien species (Table 3). First, I assumed that species of Cosmopolitan, Holarctic, and Palaearctic geographical distribution likely represent a major proportion of the alien element of the New Caspian plain flora because their evolution occurred out of the Caspian region. The other two sources were databases of alien plants of Europe (DAISIE, Delivering Alien Invasive Species Inventories for Europe, 2008) and of Eastern Europe/Middle Russia (AliS, 2005). Table 3 includes 160 species: 100 species with Cosmopolitan, Holarctic, and Palaearctic distributions, 105 species listed in DAISIE, and 119 species listed in AliS. Interestingly, about $70 \%$ of the species in DAISIE and $>50 \%$ of the species in AliS are Cosmopolitan, Holarctic, or Palaearctic. Although in most cases we cannot determine specifically where these more widely-distributed species originated or in what historical period they entered a particular territory, these high proportions of alien species with wide geographic distributions support my assumption that plants with Cosmopolitan, Holarctic, and Palaearctic distribution potentially are alien to the Caspian coast.

Next, I compared this preliminary list with the Flora of Kazakhstan and determined if each species occurred in natural areas in the study area, in disturbed areas, or in both. A total of 95 of the potentially alien species were listed in the Flora of Kazakhstan and occurred only in natural habitats in Kazakhstan (mostly in coasts of seas, lakes, floodplains, and saline lands). These species included Phragmites australis, Scirpus lacustris, Butomus umbellatus, Halimione pedunculata, Tripolium pannonicum, and T. vulgare. Thus, these species (marked with an asterisk in Table 3), are 
Table 3 Potentially alien species in the flora of the northeastern cost of the Caspian Sea

\begin{tabular}{|c|c|c|c|}
\hline \multirow{2}{*}{ Species } & \multirow{2}{*}{ Geographic distribution } & \multicolumn{2}{|c|}{ Presence in database } \\
\hline & & DAISI, 2008 & AliS, 2005 \\
\hline \multicolumn{4}{|l|}{ Alismataceae Vent. } \\
\hline * Alisma plantago-aquatica L. & Palaearctic & - & - \\
\hline \multicolumn{4}{|l|}{ Amaranthaceae Juss. } \\
\hline Amaranthus albus L. & Cosmopolitan (North America) & + & + \\
\hline A. retroflexus L. & Cosmopolitan (North America) & + & + \\
\hline \multicolumn{4}{|l|}{ Asparagaceae Juss. } \\
\hline ? Asparagus officinalis L. & Palaearctic & - & + \\
\hline \multicolumn{4}{|l|}{ Asteraceae Dumort. } \\
\hline Achillea micrantha Willd & Palaearctic & + & + \\
\hline * Acroptilon australe Iljin & E-medit & - & + \\
\hline A. repens (L.) DC. & Palaearctic & + & + \\
\hline Arctium tomentosum Mill. & Palaearctic & + & + \\
\hline ? Artemisia austriaca Jacq. & Palaearctic & + & + \\
\hline ? A. dracunculus $\mathrm{L}$. & Holarctic & - & + \\
\hline * A. lerchiana Web.et Stechm. & Pontic-N-turan & - & + \\
\hline * A. santonica $\mathrm{L}$. & Pontic-Caspian & - & + \\
\hline * A. schrenkiana Ledeb. & E-medit & + & - \\
\hline A. sieversiana Willd. & Palaearctic & + & + \\
\hline * Bidens tripartita L. & Palaearctic & + & - \\
\hline * Centaurea arenaria M.B. & Caspian & - & + \\
\hline Cirsium arvense (L.) Scop. & Palearctic & + & - \\
\hline Coniza canadensis (L.) Cronq. & Holarctic (North America) & + & + \\
\hline ? Crepis tectorum $\mathrm{L}$. & Palaearctic & + & - \\
\hline ? Inula britannica L. & Palaearctic & + & - \\
\hline ? I. salicina $\mathrm{L}$. & Palaearctic & - & - \\
\hline Lactuca serriola $\mathrm{L}$. & Palaearctic & + & + \\
\hline * L. tatarica (L.) C. A. Mey. & Medit & + & + \\
\hline * Saussurea amara (L.) DC. & E-medit & - & + \\
\hline * S. noeanus Rupr & N-Turan & - & + \\
\hline Sonchus arvensis L. & Holarctic & + & + \\
\hline * Tanacetum millefolium (L.) Tzvel. & Palaearct & + & - \\
\hline Taraxacum officinale Willd. & Cosmopolitan & + & - \\
\hline * Tripolium pannonicum (Jacq.) Dobrocz. & Palaearctic & - & - \\
\hline * T. vulgare Nees & Palaearctic & - & + \\
\hline Xanthium spinosum L. & Holarctic (North/South America) & + & + \\
\hline X. strumarium L. & Holarctic (North America) & + & + \\
\hline \multicolumn{4}{|l|}{ Boraginaceae Juss. } \\
\hline *Argusia sibirica (L.) Dandy & E-medit & + & + \\
\hline ? Arnebia decumbens (Vent.) Coss. \& Kral. & Palaearctic & + & - \\
\hline ? Asperugo procumbens L. & Palaearctic & + & - \\
\hline * Heliotropium ellipticum Ledeb. & Pontic-Iran-turan & + & + \\
\hline * Lappula echinata Gilib. & Palaearctic & - & - \\
\hline ? L. marginata (M.B.) Gurke. & Palaearctic & + & - \\
\hline ? L. patula (Lehm.) Men & Palaearctic & - & + \\
\hline ? Nonea pulla DC. & Palaearctic & + & + \\
\hline * Onosma tinctorium M.B. & Pontic-N-turan & - & + \\
\hline
\end{tabular}


Continued

\begin{tabular}{|c|c|c|c|}
\hline \multirow{2}{*}{ Species } & \multirow{2}{*}{ Geographic distribution } & \multicolumn{2}{|c|}{ Presence in database } \\
\hline & & DAISI, 2008 & AliS, 2005 \\
\hline \multicolumn{4}{|l|}{ Brassicaceae Burnett } \\
\hline * Alyssum turkestanicum Regel \& Schmalh. & Medit & + & + \\
\hline Capsella bursa-pastoris $\mathrm{L}$. & Cosmopolitan & + & + \\
\hline * Cardaria draba (L.) Desv. & Palaearctic & + & + \\
\hline * C. pubescens (C. A. Mey.) Jarm. & E-medit & + & + \\
\hline * Chorispora tenella (Pall.) DC. & E-medit & + & + \\
\hline * Clypeola jonthlapsi $\mathrm{L}$. & Medit & + & + \\
\hline Descurainia sophia (L.) Webb ex Prantl & Holarctic & + & + \\
\hline * Erysimum leucanthemum (Steph.)B.Fedtsch. & E-medit & - & + \\
\hline * Isatis tinctoria $\mathrm{L}$. & Medit & + & + \\
\hline ? Lepidium latifolium $\mathrm{L}$. & Palaearctic & + & + \\
\hline * L. perfoliatum $\mathrm{L}$. & Palaearctic & + & + \\
\hline L. ruderale $\mathrm{L}$. & Palaearctic & + & + \\
\hline * Meniocus linifolius (Steph.) DC. & Medit & - & + \\
\hline Sisymbrium loeselii $\mathrm{L}$. & Palaearctic & + & + \\
\hline * Syrenia montana (Pall.) Klok. & Palaearctic & - & + \\
\hline * S. siliculosa (M Bieb) Andrz. & E-medit & - & + \\
\hline \multicolumn{4}{|l|}{ Butomaceae Rich. } \\
\hline * Butomus umbellatus $\mathrm{L}$. & Palaearctic & + & - \\
\hline \multicolumn{4}{|l|}{ Caryophyllaceae Juss. } \\
\hline ? Gypsophila paniculata $\mathrm{L}$. & Palaearctic & + & + \\
\hline ? G. perfoliata $\mathrm{L}$. & Palaearctic & + & + \\
\hline \multicolumn{4}{|l|}{ Chenopodiaceae Vent. } \\
\hline * Agriophyllum squarrosum (L.) Moq. & E-medit & - & + \\
\hline * Atriplex aucheri Moq. & Iran-Turan & + & + \\
\hline * A. laevis C.A.Mey. & E-medit & - & + \\
\hline Atriplex littoralis $\mathrm{L}$. & Palaearctic & + & + \\
\hline * A. oblongifolia Waldst. \&Kit. & Holarctic & + & + \\
\hline A. patula $\mathrm{L}$. & Palaearctic & + & + \\
\hline ? A. prostrata Boucher ex DC. & Palaearctic & + & + \\
\hline * A. sagittata Borkh. & Palaearctic & - & + \\
\hline * A. tatarica $\mathrm{L}$. & Medit & + & + \\
\hline * Bassia hyssopifolia (Pall.) O. Kuntze & E-medit & + & + \\
\hline * B. sedoides (Pall.) Aschers. & E-medit & + & + \\
\hline Chenopodium album $\mathrm{L}$. & Cosmopolitan & + & + \\
\hline Ch. chenopodioides (L) Aellen & Holarctic & + & + \\
\hline Ch. ficifolium Smith. & Holarctic & + & + \\
\hline Ch. glaucum L. & Holarctic & + & + \\
\hline ? Ch. rubrum $\mathrm{L}$. & Holarctic & + & + \\
\hline * Climacoptera brachiata (Pall.) Botsch. & E-medit & - & + \\
\hline * Corispermum hyssopifolium L. & Pontic-N-turan & + & + \\
\hline *C. orientale Lam. & Medit & + & + \\
\hline * Halimione pedunculata (L.) Aell. & Palaearctic & - & - \\
\hline * Kochia densiflora (Moq.) Aell. & E-medit & - & + \\
\hline * K. prostrata (L.) Schrad. & Medit & - & + \\
\hline ? K. scoparia Schrad. & Palaearctic & + & + \\
\hline * Salicornia europaea $\mathrm{L}$. & Cosmopolitan & - & + \\
\hline * Salsola australis (R.) Br. & Palaearctic & - & + \\
\hline
\end{tabular}


Continued

\begin{tabular}{|c|c|c|c|}
\hline \multirow{2}{*}{ Species } & \multirow{2}{*}{ Geographic distribution } & \multicolumn{2}{|c|}{ Presence in database } \\
\hline & & DAISI, 2008 & AliS, 2005 \\
\hline * S. nitraria Pall. & Medit & - & + \\
\hline * S. soda L. & Medit & - & + \\
\hline * Suaeda altissima (L.) Pall. & Medit & + & + \\
\hline * S. prostrata Pall. & E-Medit & - & + \\
\hline \multicolumn{4}{|l|}{ Convolvulaceae Juss. } \\
\hline Calystegia sepium (L.) R.Br. & Cosmopolotan & + & - \\
\hline Convolvulus arvensis $\mathrm{L}$. & Cosmopolitan & + & - \\
\hline \multicolumn{4}{|l|}{ Cyperaceae Juss. } \\
\hline * Bolboschoenus maritimus (L.) Palla & Cosmopolitan & - & - \\
\hline * Eleocharis acicularis Roem. Et Schult. & Cosmopolitan & - & - \\
\hline * Scirpus lacustris L. & Palaearctic & - & - \\
\hline * S. tabernaemontani C. C. Gmel. & Palearctic & - & + \\
\hline \multicolumn{4}{|l|}{ Euphorbiaceae Juss. } \\
\hline * Euphorbia seguierana Neck. & Palaearctic & + & + \\
\hline \multicolumn{4}{|l|}{ Fabaceae Lindl. } \\
\hline * Glyzyrrhiza echinata $\mathrm{L}$. & Pontic-N-turan & + & + \\
\hline * G. glabra L. & Medit & + & + \\
\hline * G. korshinskyi G.Grig. & Trans-Volga-Kaz & - & + \\
\hline * Halimodendron halodendron (Pall.) Voss. & Medit & + & + \\
\hline Melilotus albus Desr. & Palaearctic & + & + \\
\hline * Pseudosophora alopecuroides (L.) Sweet & E-Medit & - & + \\
\hline * Trigonella orthoceras Kar. Et Kir. & Medit & + & - \\
\hline \multicolumn{4}{|l|}{ Fumariaceae DC. } \\
\hline Fumaria officinalis L. & Palaearctic & + & + \\
\hline * F. vaillantii Loisel. & Medit & + & + \\
\hline \multicolumn{4}{|l|}{ Juncaceae Juss. } \\
\hline * Juncus compressus Jacq. & Palaearctic & - & - \\
\hline * J. gerardii Loisel. & Palaearctic & + & + \\
\hline \multicolumn{4}{|l|}{ Lamiaceae Lindl. } \\
\hline Lycopus exaltatus L. & Palaearctic & + & - \\
\hline Mentha arvensis $\mathrm{L}$. & Palaearctic & + & - \\
\hline \multicolumn{4}{|l|}{ Lythraceae Jaume. } \\
\hline * Lythrum virgatum $\mathrm{L}$. & Palearctic & - & + \\
\hline \multicolumn{4}{|l|}{ Limoniaceae Lincz. } \\
\hline * Limonium gmelinii Willd. O. Kuntze & Medit & - & + \\
\hline \multicolumn{4}{|l|}{ Malvaceae Juss. } \\
\hline Abutilon theophrasti Medik. & Cosmopolitan & + & + \\
\hline ? Althaea officinalis L. & Palaearctic & + & + \\
\hline \multicolumn{4}{|l|}{ Plantaginaceae Juss. } \\
\hline Plantago major L. & Palaearctic & + & - \\
\hline \multicolumn{4}{|l|}{ Poaceae Barnhart } \\
\hline * Agropyron desertorum (Fisch. ex Link) Schult. & E-Medit & + & + \\
\hline * A. fragile (Roth) P. Candargy & E-Medit & + & + \\
\hline * Agrostis gigantea Roth. & Palaearctic & - & - \\
\hline * Anisantha tectorum (L.) Nevski & Medit & + & + \\
\hline ? Bromopsis inermis Leyss. & Palaearctic & + & + \\
\hline * Calamagrostis epigeios (L.) Roth. & Palaearctic & - & - \\
\hline
\end{tabular}


Continued

\begin{tabular}{|c|c|c|c|}
\hline \multirow{2}{*}{ Species } & \multirow{2}{*}{ Geographic distribution } & \multicolumn{2}{|c|}{ Presence in database } \\
\hline & & DAISI, 2008 & AliS, 2005 \\
\hline * C. pseudophragmites (Hall.fil.) Koel. & Palaearctic & - & - \\
\hline Crypsis schoenoides (L.) Lam. & Palaearctic & + & - \\
\hline Cynodon dactylon (L.) Pers. & Palaearctic & + & + \\
\hline Digitaria ischaemum (Schreb.) & Palaearctic & + & - \\
\hline ? Elytrigia repens (L.) Nevski & Palaearctic & + & - \\
\hline * Eragrostis minor Host. & Palaearctic & + & + \\
\hline * Eremopyrum bonaepartis (Spreng.) Nevski & Medit & + & - \\
\hline * E. orientale (L.) Jaub. et Spach. & Medit & + & + \\
\hline * E. triticeum (Gaertn.) Nevski & Medit & + & + \\
\hline * Leymus multicaulis (Kar.et Kir.) Tzvel. & E-Medit & + & + \\
\hline * L. paboanus Claus. & E-Medit & - & + \\
\hline * L. ramosus (Trin.) Filat. & E-Medit & - & + \\
\hline * L. racemosus (Lam.) Tzvel. & Palaearctic & + & + \\
\hline * Phragmites australis (Cav.) Trin. ex Steud. & Cosmopolitan & - & - \\
\hline * Poa bulbosa $\mathrm{L}$. & Holarctic & + & + \\
\hline * Puccinellia distans (Jacq.) Parl. & Palaearctic & + & + \\
\hline * P. gigantea (Grossh.) Grossh. & Turan & + & + \\
\hline * Stipa capillata $\mathrm{L}$. & Trans-Volga-Kaz & + & + \\
\hline * S. lessingiana Trin. et Rupr. & E-Medit & - & + \\
\hline \multicolumn{4}{|l|}{ Polygonaceae Juss. } \\
\hline ? Persicaria hydropiper (L.) Spach & Palaearctic & + & - \\
\hline Polygonum argyrocoleon Steud. ex G.Kunze & Palaearctic & + & + \\
\hline P. aviculare $\mathrm{L}$. & Cosmopolitan & + & + \\
\hline * P. monspeliense Thieb. ex Pers. & Palaearctic & - & - \\
\hline P. patulum Bieb. & Palaearctic & + & + \\
\hline ? Rumex confertus Willd. & Palaearctic & + & + \\
\hline * R. marschallianus Reichenb. & Medit & - & + \\
\hline ? R. stenophyllus Ledeb. & Palaearctic & + & + \\
\hline * R. ucrainicus Fisch. ex Spreng. & E-Medit & - & + \\
\hline \multicolumn{4}{|l|}{ Ranunculaceae Juss. } \\
\hline * Ceratocephala falcata (L.) Pers. & Medit & - & + \\
\hline * C. testiculata (Grantz.) Bess. & Medit & + & + \\
\hline \multicolumn{4}{|l|}{ Rosaceae Juss. } \\
\hline Potentilla bufurca $\mathrm{L}$. & Palaearctic & + & + \\
\hline P. supina $\mathrm{L}$. & Palaearctic & + & + \\
\hline \multicolumn{4}{|l|}{ Scrophulariaceae Juss. } \\
\hline * Dodartia orientalis L. & Medit & + & - \\
\hline \multicolumn{4}{|l|}{ Solanaceae Juss. } \\
\hline Hyoscyamus niger $\mathrm{L}$. & Palaearctic & + & + \\
\hline H. pusillus L. & Palaearctic & + & + \\
\hline Solanum nigrum $\mathrm{L}$. & Palaearctic & + & + \\
\hline \multicolumn{4}{|l|}{ Tamaricaceae Link. } \\
\hline * Tamarix ramosissima Ledeb. & Medit & + & - \\
\hline \multicolumn{4}{|l|}{ Typhaceae Juss. } \\
\hline * Typha angustifolia $\mathrm{L}$. & Holarctic & - & - \\
\hline * T. latifolia $\mathrm{L}$. & Holarctic & - & - \\
\hline * T. minima Funck & Palaearctic & - & - \\
\hline
\end{tabular}

Note: Potential species included those in the flora that had at least one of the following: (1) had a Cosmopolitan, Holarctic, or Palaearctic geographic distribution, (2) was in the DAISIE (2008) database, or (3) was in the AliS (2005) database. Species marked with an asterisk (*) were native according to the Flora of Kazakhstan and were present only in natural habitats in the study area; these species are considered "native". Species marked with a question mark (?) were also in the Flora of Kazahkstan but were present in both natural and disturbed habitats in the study area; the native/alien status of these species is uncertain. The remaining species are most likely alien species. 
considered to be native species to the region. An additional 23 species were also listed in the Flora of Kazakhstan but these species were found in both natural and disturbed areas. Thus, I am uncertain about the origin of these species (marked with a question mark in Table 3). Species with uncertain origin include $A r$ temisia austriaca, A. dracunculus, Lepidium latifolium, Kochia scoparia, and Asparagus officinalis. For some of these species with uncertain origin, part of the problem in identifying their origin may be uncertain taxonomic status. For example, Atriplex hastata L. was revised by Cherepanov (1995) as Atriplex calotheca (Rafn) Fries. But A. calotheca is endemic of the Baltic Sea coast; it is listed as vulnerable plant in nature protected areas near Sankt-Petersburg (Siluyanov, 2007). In contrast, a monograph of the genus Atriplex (Suchorukow, 2003) included Atriplex hastata into Atriplex prostrata Pall. as synonyms. It was thought that the origin of $A$. prostrata is in the steppe and semidesert areas of Eurasia. To understand the actual native/alien status of these uncertain species, additional information is needed, including careful investigations of herbarium specimens in Kazakhstan (AA), Uzbekistan (TASH), and Russia (LE).

The remaining 42 species in Table 3 were listed in the Flora of Kazahkstan but occur only in disturbed habitats in the Caspian region, have a Cosmopolitan, Holarctic, or Palaearctic distribution, and occur in at least one of the two alien species databases (and 83\% of these 42 species occur in both alien species databases). Thus, these 42 species, which comprise about $12 \%$ of the total flora, are most likely alien species. These species belong to 14 families and 32 genera. Species of Asteraceae, Chenopodiaceae, Brassicaceae, and Poaceae families prevail. Life forms of therophytes (52\%) and hemicriptophytes (48\%) are the most common. Ecological group of mesophytes (60\%) prevail; other ecological groups include xeromesophytes (26\%), mesoxerophytes $(10 \%)$, and hygrophytes and xerophytes $(2 \%)$, respectively.

We have almost no specific data about the timing, routes, and means of species migrations except for plants of North and South American origin. Most likely, migration occurred as a result of direct or indirect human activities because the Caspian Sea lies along the ancient caravan routes of the Silk Road that connected Europe and Asia. Some species are weeds of agricultural fields: Sonchus arvensis, Convolvulus arvensis, Solanum nigrum, Chenopodium album, Acroptilon repens, etc. These species likely entered the territory with grain and fodder as well as during agricultural development of the region in the $20^{\text {th }}$ century. For the two Xanthium species that originated from the Americas, $X$. strumarium is widespread and usually is in waterways in the Caspian region. Xanthium spinosum initially was rare after introduction, but it is becoming more abundant now in disturbed habitats. Along the Caspian coast, this species prefers well drained habitats along roads, wetlands, and canals.

Six species, Amaranthus albus, A. retroflexus, Anisantha tectorum (called Bromus tectorum outside the former Soviet Union), Atriplex tatarica, Cardaria draba, and Puccinellia distans, are also listed in the Black Book of Invasive Plants of Eastern Europe (Vinogradova et al., 2009). However, Puccinellia distans is not an invasive plant but occurs naturally in salt meadows of the Caspian Sea coast (together with $P$. dolicholepis). Anisantha tectorum also is a natural component of sand deserts. Atriplex tatarica is a native plant that is increasing coverage in degraded lands. Cardaria draba is widely spread in natural areas including the Caspian region; however, it is not aggressive and does not become a dominant in plant communities. Only Amaranthus albus and A. retroflexus have invasive features, especially the latter. They were introduced during the $18^{\text {th }}$ century from North America to Europe. Since that time, they have spread widely. In Central Asia, these species appeared in the early 1900s. They have naturalized in riparian habitats and flood plains in Central Asia and have become pioneers during colonization of river banks.

Some species of the DAISIE database show invasive characteristics in the study area: above mentioned Xanthium strumarium and X. spinosum, along with Lepidium ruderale, Descurainia sophia, Achillea micrantha, and Atriplex prostrata. Lepidium ruderale is a typical plant that grows in waste areas and fallow land as well as along roads and canals. Descurainia sophia is often found in natural habitats with low abundance, but in disturbed areas (overgrazed, burned 
areas), it can be a dominant plant. Achillea micrantha has gradually dominated man-made habitats. Atriplex prostrata grows in abandoned fields. This plant is very interesting because it can be a pioneer during colonization of the transition zone between sea and land. In anthropogenic habitats, species of Mediterranean and Eastern Mediterranean areas are common: Bassia hyssopifolia, B. sedoides, Climacoptera brachiata, Suaeda altissima, Pseudosophora alopecuroides, Eremopyrum orientale, E. triticeum, Ceratocarpus arenarius, and Peganum harmala as well as some Palaearctic plants: Euphorbia seguierana, Lepidium latifolium, L. perfoliatum, Kochia scoparia, and Lactuca serriola. Dimeyeva and Pankratova (2011) documented $114(33 \%)$ weed and ruderal species in the Caspian Sea coast, which included both native (apophytes) and alien (anthropophytes) species.

\section{Conclusions}

Analysis of taxonomic, life form and ecological structure of the New Caspian marine plain flora clearly shows the dominance of species adapted to arid desert conditions and highly saline soils. The most abundant plant families and genera of the Caspian Sea coast are typical for deserts of Kazakhstan and Middle Asia. Among life forms, therophytes, hemicryptophytes, and chamaephytes prevail, which is consistent with the need for plants to survive summer drought as well as winter cold. The predominant ecological group of species is xeromesophytes, which is represented by both annual and perennial ephemeral species that are adapted to short wet periods in arid climates. One-third of the species list is halophytes, both annual and perennial saltworts and salt tolerant grasses that are typical for saline soils of the Caspian Sea coast. Geographical analysis of species ranges shows that the majority of species have a Mediterranean origin that is associated with the Ancient Mediterranean territory. Species of desert provinces of Central Asia number one fifth of the flora of the New Caspian marine plain. Some species $(10 \%)$ are originated in the Black Sea - Kazakhstan steppe subregion, providing a connection of the study area to the northern type of deserts (i.e. steppe deserts/desert with grasses, Rachkovskaya et al., 2003) and an influence of steppe vegetation. Species of wide geographical distribution (Cosmopolitan, Holarctic, and Palaearctic) comprise $29 \%$ of the flora, but only a small proportion of the flora $(2.6 \%)$ has a Caspian and Aralo-Caspian origin.

Although I initially identified 160 potentially alien species in the flora, only 42 species $(12 \%$ of the total flora) are likely aliens, with another 23 species with uncertain native/alien status. Leading families are similar to the overall flora; species of Asteraceae, Chenopodiaceae, and Brassicaceae families prevail. Only therophytes and hemicriptophytes are among life forms. For comparison, alien elements of the nearby Astrakhan region (the lower reaches and delta of the Volga River) comprise a similar percentage (13\%) of the flora (Laktionov, 2010).

Although among these alien species are several species with invasive features, severe environmental conditions of the northern deserts and high salinity of soils and ground waters lessen the opportunities for exotic plant invasions. Today however, anthropogenic disturbance from oil production development and construction of roads, dams, and pipelines complicates natural ecological processes, and new alien species have the potential to reach the area through accompanying increases in transportation, trade, and economic activity. Thus, monitoring of alien plants is an important task for the future.

\section{Acknowledgements}

Thanks to the organizers and supporters of the International Symposium on Invasive Plants and Global Change in Urumqi, China in 2012 for their commendable work in building a successful meeting.

\section{References}

Akiyanova F Z, Medeu A R, Nurmambetov E I, et al. 2006. Geomorphology. Republic of Kazakhstan. Almaty: Orint-S, 1: 171-214.

Aladin N V, Plotnikov I S. 2000. Palaeolimnology and palaeosalinity of the Caspian Sea and its precursors for the last 15 million years. Caspian Floating University Research Bulletin, 1: 51-64. Alien plant Species of Eastern Europe (AliS). 2005. Database. [2005-12-12]. http://www.sevin. ru/invasive/dbases/plants.html. Burlibayev M Z, Kurochkina L Y. 2007. Globally Important Wetlands of Kazakhstan. Kazakhstan: Astana, 264. 
Caspian Sea, GIWA Regional assessment 23. 2006. UNEP. Sweden: University of Kalmar.

Cherepanov S K. 1995. Vascular plants of Russia and adjacent states (the former USSR). New York: Cambridge University Press, 516.

DAISIE Europe Invasive Alien Species Gateway. 2008. Delivering Alien Invasive Species Inventories for Europe. Terrestrial plants. Accessed $1^{\text {st }}$ February 2008. [2008-02-15]. http://www. europe-aliens.org.

Diarov M, Gilazhov E, Dimeyeva L, et al. 2003. Ecology and oil and gas complex. Almaty: Gylym, 340.

Dimeyeva L A. 2011. Mechanisms of Primary Successions on the Caspian Sea Coast. Arid Ecosystems, 1 (3): 149-158.

Dimeyeva L A, Pankratova I V. 2011. Peculiarities of the Aral Sea and the Caspian Sea marine plains flora. Bulletin of Penza State Pedagogical University, Biology Series, 3: 54-59.

Dzharmagambetov T.Zh. 1987. Analysis of Flora of Caspian Depression in the Limits of Kazakhstan. Alma-Ata: Nauka, 25.

Faizov K Sh. 1970. Soils of Guriev oblast. Alma-Ata: Nauka, 352.

Flora of Kazakhstan.1956-1966. Alma-Ata: Nauka, 1-9.

Kislov A, Panin A, Toropov P. 2012. Palaeostages of the Caspian Sea as a set of regional benchmark tests for the evaluation of climate model simulations. Clim. Past Discuss, 8: 5053-5081. [2012-10-10]. www.clim-past- discuss.net/8/5053.

Laktionov A.P. 2010. Flora of Astrakhan Oblast, Its Analysis and Current State. Astrakhan: State University, 46.

Lavrenko E M. 1962. Main features of botanical geography of deserts in Eurasia and North Africa. Moscow-Leningrad: Nauka, 168.

Lavrenko E M. 1970. Regionalization of Black Sea-Kazakhstan subregion of Eurasian steppe region. Botanical Journal, 55: 5.
Lavrushin Y, Leonov Y, Lilienberg D. 2001. Directions and results of influence of geological factors on the fluctuations of the level of the Caspian Sea. Global changes of the natural environment. Novosibirsk: SB RAS, 105-130.

Lazareva V G. 2003. Botanical diversity of ecosystems of North-Western Caspian region in conditions of oscillation of the Caspian Sea level. Elista, 206.

Levina F Y. 1964. Vegetation of semi-desert Northern Caspian region and its importance as forage. Moscow-Leningrad: Nauka, 336.

National Atlas of the Republic of Kazakhstan. 2010. Almaty: Print-S, 125.

Rachkovskaya E I, Volkova E A, Khramtsov V N. 2003. Botanical Geography of Kazakhstan and Middle Asia (Desert Region). St Petersburg: Boston-Spectr, 424.

Raunkiaer C. 1910. Statistics of the life forms as a basis for biological plant geography. Booklet Botanical Centralsheet, 27(II): 171-206.

Siluyanov A N. 2007. Development plan for protected area "Kurgalskiy". Project LIFE04 TCY/ROS/000050: "Bringing regional protected areas of the Leningrad Region (Russian Federation) into European Context. St Petersburg, 72.

Suchorukow A P. 2003. Distribution of Atriplex L. species (Chenopodiaceae) in Russia and contiguous States (in the limits of USSR). Bulletin of Moscow Society of Naturalists, 108 (1): 38-50.

Svitoch A. 1991. Oscillation of the Caspian Sea in Pleistocene. The Caspian Sea: Paleogeography and Geomorphology. Moscow: Nauka, 1-100.

Vinigradova Y K, Majorov S R, Khorun L V. 2009. Black book of the Middle Russia flora (Alien plant species in ecosystems of Middle Russia). Moscow: GEOS, 494. 